\title{
Analisis Proses Pembelajaran IPA Terpadu Dalam Pelaksanaan Kurikulum 2013 Di SMP Kecamatan Sumur - Banten
}

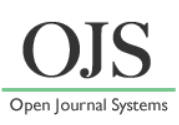

\author{
Devi Febriyanti*, Sjaifuddin, Lulu Tunjung Biru \\ Program Studi Pendidikan IPA, FKIP, Universitas Sultan Ageng Tirtayasa \\ *Email:devifebriyanti332@gmail.com \\ DOI: https://doi.org/10.33369/pendipa.6.1.218-225
}

\begin{abstract}
The purpose of this study was to find out how the results of the analysis of the integrated science learning process in the implementation of the 2013 curriculum in SMP Sumur sub-district. The method used in this study is a qualitative descriptive research method. The subjects in this study were 5 science teachers, 5 principals, and 5 students. This research was carried out at the Sumur sub-district junior high school which was carried out in 5 schools. The research was carried out in the academic year 2020-2021 odd semester. The results obtained in the study came from the results of questionnaires and interviews. The data obtained from this study indicate that overall junior high schools in Sumur sub-district have implemented the 2013 curriculum very well, but some obstacles were found in its implementation, namely an understanding of integration in accordance with the 2013 curriculum and there are still many teachers who use the lecture method when implementing learning, causing students to become less active during learning.
\end{abstract}

Keywords: Learning process, Integrated Science, Curriculum 2013.

\begin{abstract}
ABSTRAK
Tujuan dari penelitian ini adalah untuk mengetahui bagaimana hasil analisis proses pembelajaran IPA terpadu dalam pelaksanaan kurikulum 2013 di SMP kecamatan Sumur. Metode yang digunakan dalam penelitian ini merupakan metode penelitian deskriptif kualitatif. Subjek dalam penelitian ini adalah 5 guru IPA, 5 kepala sekolah, dan 5 siswa. Penelitian ini dilaksanakan di SMP kecamatan Sumur yang dilaksanakan di 5 sekolah. Penelitian dilaksanakan pada tahun ajaran 2020-2021 semester ganjil. Hasil yang didapatkan dalam penelitian berasal dari hasil angket dan wawancara. Perolehan data hasil penelitian ini menunjukan bahwa secara keseluruhan SMP di kecamatan Sumur sudah melaksanakan kurikulum 2013 dengan sangat baik akan tetapi ditemukan beberapa kendala dalam pelaksanaannya yaitu pemahaman mengenai keterpaduan yang sesuai dengan kurikulum 2013 serta masih banyaknya guru yang menggunakan metode ceramah ketika pelaksanaan pembelajaran sehingga menyebabkan siswa menjadi kurang aktif pada saat pembelajaran berlangsung.
\end{abstract}

Kata kunci: Proses pembelajaran, IPA Terpadu, Kurikulum 2013.

\section{PENDAHULUAN}

Pendidikan merupakan usaha sadar dan terencana untuk mewujudkan suasana belajar dan proses pembelajaran agar siswa secara aktif mengembangkan potensi dirinya melalui pengajaran, bimbingan dan latihan sehingga nantinya dapat digunakan sebagai bekal dan manfaat untuk kepentingan dirinya sendiri ataupun masyarakat. Menurut Prasetiyono S (2014) Selama ini proses pembelajaran dipengaruhi oleh dua faktor yaitu faktor internal dan faktor eksternal, dimana faktor internal berasal dari diri siswa itu sendiri misalnya minat dan bakat, kecerdasan emosional, kecerdasan intelektual, dan motivasi. sedangkan faktor eksternal meliputi sarana dan prasarana, kurikulum, media pembelajaran dan cara belajar.

Selain kedua faktor tersebut interaksi anatara guru dan siswa sangatlah penting karena berkaitan erat dalam menunjang keberhasilan pembelajaran. Untuk mencapai tujuan pembelajaran maka harus adanya pendidikan 
yang berkualitas, dimana pendidikan yang berkualitas sangat erat kaitannya dengan pelaksanaan kurikulum, Untuk menciptakan sekolah dengan suasana belajar yang menyenangkan maka dibutuhkan perubahan yang cukup mendasar dalam sistem pendidikan, perubahan tersebut digunakan untuk menyempurnakan kurikulum yang baru karena kurikulum merupakan suatu perangkat yang penting digunakan sebagai pedoman kegiatan pembelajaran disekolah

Menurut Radimah (2019) menyatakan bahwa salah satu permasalahan terbesar dalam dunia pendidikan di indonesia adalah pemerataan kualitas pendidikan. Hal ini berkaitan dengan luasnya wilayah geografis Indonesia. Sehingga Indonesia sudah mengalami beberapa kali perubahan kurikulum. Tahun 2013/2014 secara bertahap kurikulum 2013 di implementasikan sebagai pengganti dari kurikulum KTSP. Perubahan kurikulum 2006 (KTSP) menjadi kurikulum 2013 merupakan upaya pemerintah untuk memperbaiki mutu pendidikan di Indonesia..

Perbaikan mutu pendidikan dapat dimulai dari pendidik terlebih dahulu, hal ini dikarenakan pendidik memiliki tugas dan fungsi yang berhubungan langsung dengan siswa. Dimana dalam proses pembelajaran IPA terpadu yang berkualitas tidak terlepas dari seorang pendidik yang berkualitas juga. Namun banyak kendala yang ditemukan oleh guru, kendala tersebut menjadi pemicu ke tidak berhasilan pembelajara pada siswa. Menurut Setiawati (2013) perbaikan mutu pendidikan dapat dimulai dari pendidik, hal ini dikarenakan pendidik memiliki tugas dan fungsi yang berhubungan langsung dengan peserta didik.

Pembelajaran IPA yang baik harus memiliki konten IPA yang benar diajarkan dua kompetensi yang baik, yaitu penguasaan konsep pedagogi yang baik, dan yang kedua adalah penguasaan konten. Dimana Cochran (1993) menyatakan bahwa pemahaman yang dimiliki oleh guru agar dapat mengajar dengan baik yaitu pemahaman terkait dengan isi materi/konten, pengetahuan pedagogi, dan cara membelajarkan konten. Hal ini tentu saja menjadi penghambat pembelajaran IPA, dimana sebelumnya guru IPA berasal dari disiplin ilmu pendidikan biologi, fisika dan kimia. Sedangkan menurut Purwanti (2013) penerapan pembelajaran IPA idealnya harus berdasarkan empat standar, diantarnya didasarkan pada standar isi akan membentuk siswa yang memiliki bekal ilmu pengetahuan; Standar proses akan membentuk siswa yang memiliki keterampilan ilmiah, keteramplan berfikir dan strategi berfikir; Standar inkuiri ilmiah akan membentuk siswa berfikir kritis dan kreatif; dan standar asesmen, yang digunakan untuk mengevaluasi siswa.

Perubahan kurikulum ini merupakan suatu tuntutan, namun disisi lain perubahan kurikulum membutuhkan kesiapan dalam banyak aspek, seperti masalah kemampuan guru, buku pelajaran baru, mekanisme pembelajaran dan lain sebagainya. Hubungan antara guru dengan kurikulum adalah hubungan pendidikan yang saling berkesinambungan untuk mencapai tujuan pendidikan. Dimana kuriklum 2013 menuntut perubahan dari pola teaching centered learning (TCL) ke arah student centered learning (SCL). Hal ini berarti siswa harus didorong oleh kesadaran yang tinggi dalam dirinya untuk belajar.

Berdasarkan wawancara dengan salah satu guru SMP di kecamatan sumur di peroleh informasi bahwa sekolah tersebut sudah menerapkan proses pembelajaran kurikulum 2013. akan tetapi dalam proses pembelajaran guru masih memiliki banyak kendala dalam pembelajaran IPA terpadu pada pelaksanaan kurikulum 2013 yaitu guru kesulitan dalam mengajak siswa berperan aktif dalam proses pembelajaran, kurangnya pemahaman dalam penggunaan keterpaduan dalam materi IPA, media pembelajaran yang terbatas, $\mathrm{Hal}$ ini menyebabkan siswa kesulitan untuk berperan aktif dalam proses pembelajaran sehingga proses pembelajaran tidak berjalan dengan maksimal.

Hal ini didukung oleh hasil penelitian yang dilakukan oleh Yuliyanti (2014) menyatakan bahwa kendala guru dalam mengahadapi kurikulum 2013 dalam pembelajaran adalah kurangnya pemahaman guru mengenai kurikulum 2013 serta media pembelajaran terbatas

Menurut Septiana (2018) kompetensi keterpaduan pada pembelajaran IPA tidak dapat tercapai secara integral dan holistik, namun ketercapaiannya hanya dominan pada satu keilmuan saja. Hambatan dalam pembelajaran 
IPA terpadu akan berdampak pada sulitnya peserta didik dalam memahami pembelajaran IPA sehingga menyebabkan pembelajaran menjadi tidak optimal, selain itu proses pembelajaran IPA terpadu dalam satu semester menjadi tidak tuntas.

Berdasarkan hal diatas maka perlu adanya penelitian lebih mendalam untuk mengidentifikasi lebih lanjut mengenai proses pembelajaran IPA terpadu, maka penulis tertarik untuk melakukan penelitian yang berjudul "Analisis Proses Pembelajaran IPA Terpadu Dalam Pelaksanaan Kurikulum 2013 Di SMP kecamatan Sumur"

\section{METODE PENELITIAN}

Penelitian ini menggunakan metode penelitian deskriptif kualitatif dengan beberapa metode pengumpulan data yang terdiri dari angket dan wawancara. Subjek dalam penelitian ini adalah guru IPA, kepala sekolah dan siswa SMP di kecamatan Sumur di laksanakan di SMP/MTs yang ada di kecamatan Sumur yang terdiri dari 5 sekolah diantaranya MTs Ma Sumur, MTs Darul Afkar, SMPN 1 Sumur, SMPN 2 Sumur dan SMPN 3 Sumur. Penelitian ini dilaksanakan pada bulan Februari 2021 semester genap tahun ajaran 2020/2021.

\section{HASIL DAN PEMBAHASAN}

Berdasarkan Peraturan Menteri Pendidikan Nasional Nomor 22 Tahun 2016 proses pembelajaran IPA dalam pelaksanaan kurikulum 2013 meliputi perencanaan proses pembelajaran, pelaksanaan proses pembelajaran, penilaian hasil pembelajaran, dan pengawasan proses pembelajaran. Proses pembelajaran IPA Terpadu di SMP kecamatan Sumur sudah melaksanakan pembelajaran kurikulum 2013 dengan baik, Namun dalam pelaksanaannya ditemukan beberapa kendala yang dihadapi yaitu kurangnya pemahaman guru dalam pembelajaran terpadu, serta kesulitan membuat siswa aktif dalam pembelajaran. Dimana pembelajaran IPA terpadu pada kurikulum 2013 terdiri dari beberapa jenis keterpaduan yang digunakan menurut Fogarty (1991) diantaranya conected, shared, webed, dan intergated. Masing-masing keterpaduan tersebut dapat digunakan guru dalam pembelajaran IPA Terpadu.
Adapun hasil analisis data dari tiap indikator menunjukan bahwa sekolah di kecamatan Sumur secara keseluruhan sudah melaksanakan pembelajaran IPA Terpadu yang sesuai dengan pelaksanaan kurikulum 2013 dengan baik. Hal ini diketahui dari hasil analisis data angket yang diperoleh presentase setiap indikator sebagaimana dapat di lihat dalam gambar $1 \mathrm{di}$ bawah ini.

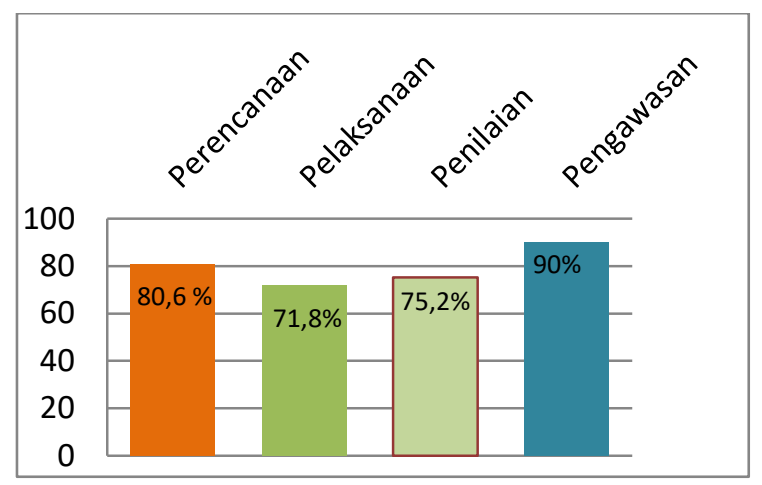

Gambar 1. Hasil analisis presentase rata-rata setiap indikator pertanyaan pada angket

Berdasarkan gambar 1, dapat dijelaskan bahwa hasil analisis pelaksanaan pembelajaran IPA Terpadu di kecamatan Sumur yang berupa data angket semua indikator diperoleh nilai ratarata presentase sebesar $79,4 \%$ dengan kriteria baik. Dimana presentase tertinggi pada indikator IV mengenai pengawasan pembelajaran yaitu sebesar 90\%, yang menunjukan bahwa proses pengawasan pembelajaran IPA terpadu yang dilakukan guru sudah dilaksanakan dengan sangat baik oleh kepala sekolah. Sedangkan untuk presentase terendah pada indikator II mengenai pelaksanaan proses pembelajaran yaitu sebesar 71,8\%, hal ini dikarenakan terdapat beberapa guru yang belum memahami pelaksanaan pembelajaran IPA Terpadu yang sesuai dengan kurikulum 2013. Berikut pembahasan lebih lanjut mengenai hasil dari tiap indikator yang digunakan dalam penelitian:

\section{Perencanaan Pembelajaran}

Perencanaan pembelajaran IPA Terpadu digunakan untuk menyusun rangcangan pembelajaran yang akan diajarkan kepada siswa, kegiatan dalam 
perencanaan pembelajaran IPA terpadu dengan cara mengidentifikasi konsep IPA dalam satu KD melalui analisis strandar kompetensi lulusan (SKL), kompetensi inti (KI), dan kompetensi dasar (KD), dimana dalam kompetensi dasar dikembangkan dengan memperhatikan karakteristik siswa, pemahaman awal, serta ciri dari suatu mata pelajaran. kemudian menentukan model keterpaduan, dimana menurut forgarty (1991) terdapat sepuluh model pembelajaran terpadu diantaranya fragmented, conected, nasted, sequenced, shared, webbed, theaded, integrated, immersed, dan network. akan tetapi hanya empat model yang cocok diterapkan dalam pembelajaran IPA Terpadu daiantaranya connected, shared, webbed, dan integrated. berikut hasil presentase penyataan angket pada indikator perencanaan pada gambar 2 di bawah ini.

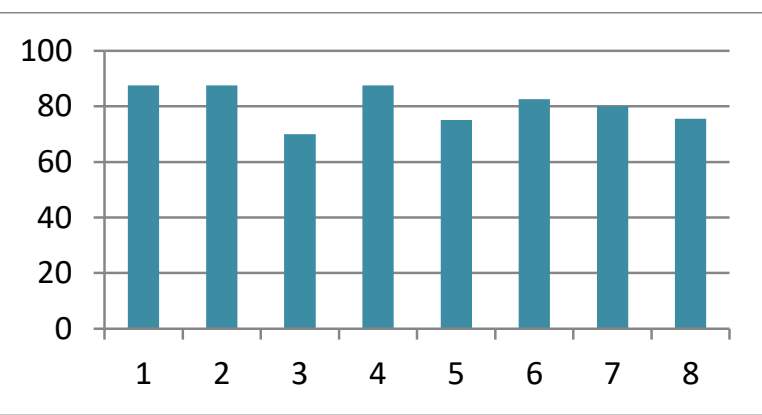

Gambar 2. Presentase angket pada indikator perencanaan

Dari gambar 2 di atas mengenai presentase angket pada indikator perencanaan pembelajaran dalam pelaksanaan kurikulum 2013 dapat diketahui bahwa rata-rata presentasenya sebesar $80,6 \%$. Presentase paling rendah terdapat pada penyusunan materi pembelajaran dengan presentase $70 \%$. Hal ini diketahui bahwa sebagian besar guru SMP dikecamatan Sumur kurang memahami mengenai pembelajaran terpadu dalam kurikulum 2013 sehingga guru kesulitan dalam menyajikan materi pembelajan yang sesuai kurikulum 2013. Pernyataan pada angket tersebut didukung oleh hasil wawancara yang disampaikan guru bahwa kesulitan yang dialami guru dalam menyusun RPP IPA Terpadu sesuai kurikulum 2013 yaitu dalam menghubungkan materi, dalam penyajian materi secara terpadu serta dalam penyusunannya.

Pada pernyataan nomor 4 dalam hal perlunya diadakannya pelatihan implementasi kurikulum 2013 memperoleh presentase sangat tinggi yaitu sebesar 87,5Hal ini didukung oleh hasil wawancara yang diketahui bahwa pemahaman guru dalam pembelajaran terpadu sangat kurang, apalagi dalam hal penggunaan keterpaduan sehingga guru merasa perlu diadakannya pelatihan implementasi kurikulum 2013. Sedangkan untuk silabus kurikulum 2013 dikembangkan sendiri oleh sekolah/MGMP sesuai dengan karakteristik dan potensi siswa pada pertanyaan nomor 5 dengan presentase $75 \%$ dengan kriteria baik. Dimana pengembangan silabus dapat dilakukan oleh para guru secara madiri atau berkelompok Musyawarah Guru Mata Pelajaran (MGMP) yang kemudian hasilnya digunakan dalam pembelajaran.

RPP disusun berdasarkan ranah kompetensi inti (KI) yaitu sikap spiritual (KI1), sikap sosial (KI2), pengetahuan KI3), dan keterampilan (KI4) dengan presentase $82,5 \%$ pada pertanyaan nomor 6 dengan kriteria sangat baik. Hal ini dapat diketahui bahwa penyusunan RPP IPA Terpadu di SMP kecamatan Sumur sudah disusun berdasarkan kompetensi inti yang sesuai dengan kurikulum 2013. Dimana kompetensi inti digunakan untuk mengembangkan sikap spiritual, sikap sosial, pengetahun dan keterampilan pada siswa.

Dalam penyusunan rencana pelaksanaan pembelajaran mencantumkan pendekatan saintifik melalui mengamati, menanya, mengumpulkan informasi, mengasosiasi, dan mengkomunikasikan memperoleh presentase $80 \%$ pada pertanyaaan nomor 7 , pendekatan saintifik dapat bermanfaat dalam mengembangkan karakter siswa serta dapat meningkatkan kemampuan berfikir siswa, sehingga siswa memperoleh untuk menyelesaikan setiap masalah yang dihadapinya, serta hasil belajar siswa menjadi tinggi.

Sedangkan pada pertanyaan nomor 8 dalam RPP kurikulum 2013 berisi model pembelajaran yang mampu menggiring siswa untuk menemukan konsep yang akan dipelajari memperoleh presentase sebesar $75 \%$ dengan kriteria baik. Hal ini dapat diketahui bahwa dalam RPP sudah menggunakan model 
pembelajaran yang mendorong siswa aktif dalam pembelajaran IPA. Dimana berdasarkan hasil wawancara guru menyebutkan bahwa dalam RPP biasanya guru menggunakan model pembelajaran problem based learning (PBL), discovery learning, dan inquiri learning.

\section{Pelaksanaan Pembelajaran}

Indikator pelaksanaan proses pembelajaran digunakan untuk mengetahui proses pelaksanaan pembelajaran yang dilakukan oleh sekolah yang ada di SMP kecamatan Sumur, dimana dalam pelaksanaan pembelajaran meliputi kegiatan pendahuluan, kegiatan inti, dan kegiatan pentup. berikut hasil presentase penyataan angket indikator pelaksanaan pembelajaran pada gambar 3 di bawah ini.

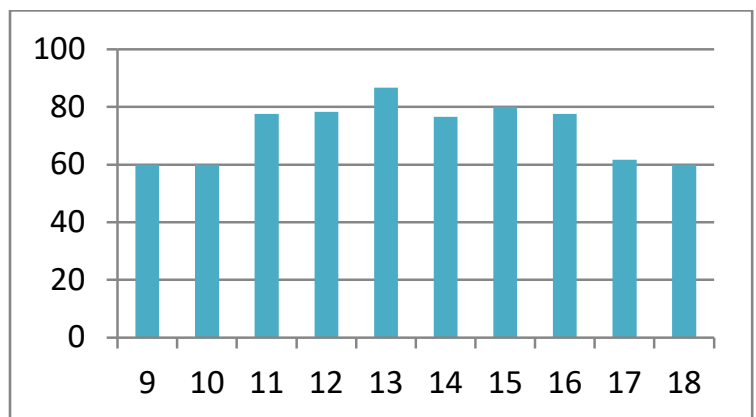

Gambar 3. Presentase angket pada indikator pelaksanaan

Dari gambar 3 mengenai presentase angket pada indikator pelaksanaan pembelajaran yang sesuai dengan kurikulum 2013 di peroleh ratarata presentase sebesar $71,8 \%$ dengan kriteria baik. Dimana dalam hal penyampaian materi pembelajaran IPA tidak disajikan menggunakan keterpaduan sebesar $60 \%$ pada nomor 9. Hal tersebut dikarenaka terdapat kendala dalam penyampaian materi menggunakan keterpaduan, dimana sebagian besar guru belum memahami mengenai keterpaduan yang sesuai dengan kurikulum 2013. Adapun hasil wawancara guru yang menyatakan bahwa guru belum memahami mengenai pembelajaran secara terpadu sesuai dengan kurikulum 2013, mulai dari model keterpaduan yang belum di pahami seperti dalam menghubungkan satu KD dengan KD lainnya.
Selanjutnya dalam hal membelajarkan IPA terpadu yang sesuai dengan sintaks yang terdapat dalam RPP dengan sebesar $60 \%$ pada nomor 10 . Dimana terdapat sekolah yang membelajarkan IPA terpadu tidak sesuai sintaks yang terdapat dalam RPP yang memiliki berbagai macam tuntutan sehingga dalam pelaksanaan pembelajaran guru menyesuaikan dengan kondisi siswa ketika mengajar.

Selain itu pada pertanyaan nomor 11 mengenai penggunaan strategi pembelajaran yang mendorong siswa aktif pada saat pelaksanaan pembelajaran memperoleh presentase $77,5 \%$ dengan kriteria baik. Hal ini dapat diketahui bahwa guru sudah merancang strategi pembelajaran yang memungkinkan siswa aktif dalam pembelajaran, akan tetapi dalam pelaksanaanya mengalami kendala atau kesulitan dalam hal membuat siswa aktif dalam pembelajaran. Hal tersebut menyebabkan tingkat ketidak aktifan siswa dalam pembelajaran sangat tinggi yaitu sebesar $78,3 \%$ pada pertanyaan nomor 12 sehingga berdampak kurang baik pada pengetahuan siswa itu sendiri, kemudian dalam penyampaian materi tidak luas dan menyeluruh pada pembelajaran yang seharusnya dipelajari.

Selain itu penggunaan metode ceramah dalam pembelajaran memiliki presentase sangat tinggi yaitu sebesar $86.6 \%$ pada pertanyaan nomor 13 Hal ini sesuai juga dengan hasil wawancara yang dilakukan kepada guru bahwa semua guru yang ada di SMP kecamatan Sumur masih menggunakan metode ceramah, dikarenkan guru kesulitan dalam menerapkan metode lain yang membuat siswa aktif dalam pembelajaran. Sehingga pembelajaran yang terjadi hanya satu arah sehingga menyebabkan siswa menjadi tidak aktif pada saat pembelajaran berlangsung. Menurut Shafa (2014) proses pembelajaran pada kurikulum 2013 lebih menekankan pada keaktifan siswa belajar secara mandiri, dalam hal ini pembelajaran pada kurikulum 2013 lebih berfokus pada siswa. Selain itu penggunaan metode ceramah kurang tepat digunakan untuk membuat siswa aktif dalam pembelajaran.

Dalam hal penerapan model pembelajaran secara inovatif memperoleh presentase sebesar $76,6 \%$ pada pertanyaan nomor 14 dengan kriteria baik. Dimana model pembelajaran yang digunakan oleh guru setiap harinya bervariasi 
disesuaikan dengan materi pembeajaran yang akan diajarkan. Hal ini digunakan untuk membuat siswa tertarik dalam pembelajaran. Selain itu interaksi guru dan siswa terjalin sangat baik, hal ini dapat dilihat dari presentase angket sebesar $80 \%$ pada nomor 15 . Kemudian dalam hal penggunaan media pembelajaran yang menarik dan bervariasi dengan presentase sebesar $77,5 \%$ pada pertanyaan nomor 16 dengan kriteria baik, media pembelajaran yang digunakan oleh guru menarik dan bervariasi yang disesuiakan dengan materi pembelajaran sehingga media pembelajarannya tidak hanya menggunakan buku pelajaran saja, misalnya media pembelajaran berupa video, penggunaan tumbuhan, dll.

Selain itu dalam pembelajaran sudah menggunakan proses pendekatan saintifik dengan presentase sebesar $61,6 \%$ pada nomor 17 , dimana proses pendekaan saintifik merupakan pendekatan yang wajib digunakan dalam pembelajaran di sekolah berdasarkan kurikulum 2013 diantaranya mengamati, menanya, mengumpulkan informasi, mengasosiasi/mengolah informasi, dan mengkomunikasikan.

Kemudian dalam penggunaan teknologi dan informasi memperoleh presentase sebesar $60 \%$ pada nomor 18 dengan kriteria cukup baik. Penggnaan teknologi dan informasi bermanfaat dalam hal penyampaian materi pembelajaran serta memudahkan siswa untuk memahami pembelajaran. Adapun berdasarkan hasil wawancara yang di sampaikan guru penggnaan teknologi dan informasi ketika pembelajaran berlangsung tatap muka di kelas tidak semua sekolah menggunakannya serta jarang digunakan dalam pembelajaran, Dimana penggunaan teknologi dan informasi bermanfaat dalam meningkatkan kualitas pembelajaran, menyajikan materi pembelajaran menjadi lebih menarik dan lain sebagainya.

\section{Penilaian Pembelajaran}

Penilaian pembelajaran dalam kurikulum 2013 terdiri tiga ranah acuan yang digunakan menurut Bloom (1981) diantaranya kognitif (pengetahuan), afektif (sikap sosial dan spiritual) dan psikomotorik (keterampilan). Dimana teknik penilaian yang digunakan dalam proses pembelajaran yaitu penilaian sikap (afektif) melalui observasi, penilaian diri, penilaian teman sejawat dan jurnal; kemudian penilaian kompetensi pengetahuan (kognitif) melalui tes tertulis maupun lisan dan penguasaan; serta penilaian kompetensi keterampilan (psikomotorik) melalui tes praktik, projek dan portofolio. Berikut presentase pernyataan angket indikator penilaian pada gambar 4 di bawah ini.

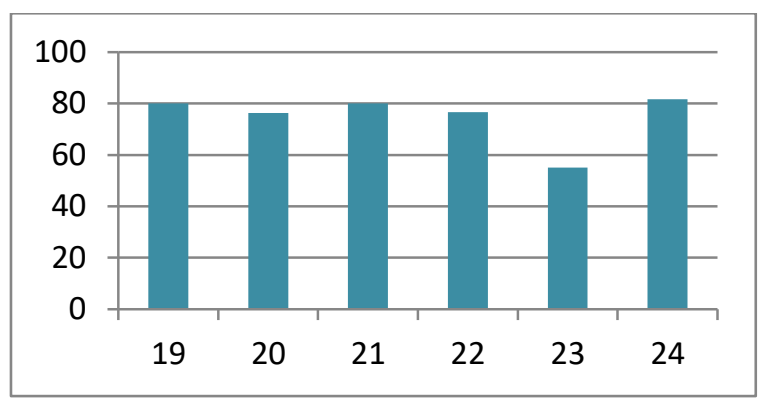

Gambar 4. Presentase angket pada indikator penilaian

Dari Gambar 4 di atas, terlihat bahwa indikator penilaian yang sesuai berdasarkan kurikulum 2013 diperoleh rata-rata presentase angket sebesar 75,2\% dengan kriteria baik. dimana sebagian besar sekolah sudah melaksanakan pretest/posttes sebelum dan sesudah melaksanakan pembelajaran dengan presentase $80 \%$ pada pertanyaan nomor 19 dengan kriteria sangat baik, hanya terdapat satu sekolah yang tidak melaksanakan pretes/posttest, kemudian dari segi materi yang digunakan dalam pretest/posttes sudah sesuai dengan materi yang diajarkan dengan presentase $78,3 \%$ pada pertanyaan nomor 20.

Kemudian dalam penggunaan instrumen penilaian sudah bervariasi untuk menilai pengetahuan, keterampilan dan sikap siswa dengan presentase angket sebesar $80 \%$ pada pertanyaan nomor 21 dengan kriteria sangat baik. hal ini dapat diketahui bahwa sekolah yang ada di SMP kecamatan sumur sudah menggunakan instrumen yang bervariasi dalam penilaian. Selain itu dalam hal memberikan penilaian kepada siswa diperoleh presentase sebesar 76,6\% pada pertanyaan nomor 22 dengan kriteria cukup baik. hal ini dikarenakan terdapat beberapa sekolah yang tidak melakukan penilaian secara objektif di antaranya sekolah C dan sekolah D, hal tersebut beranggapan bahwa sulit untuk menerapkan penilaian pembelajaran secara 
objektif dimana siswa memiliki karakter yang berbeda-beda misalnya dalam hasil ulangan siswa memiliki nilai sangat bagus, akan tetapi sering tidak masuk sekolah sehingga hal tersebut yang menjadikan sekolah tersebut tidak melakukan penilaian secara objektif.

Selain itu juga SMP yang ada di kecamatan sumur sudah memahami sistem penilaian yang sesuai dengan kurikulum 2013, hal ini diperoleh dengan presentase sebesar $55 \%$ pada pertanyaan nomor 23 yang mengalami kendala dalam penilaian. Kemudian sekolah yang ada di SMP kecamatan Sumur sudah melakukan penilaian yang mencakup pengetahuan, sikap dan keterampilan siswa dengan sangat baik, hal ini dapat dilihat dari presentase angket sebesar $81,6 \%$ pada pertanyaan nomor 24 .

\section{Pelaksanaan Pembelajaran}

Pengawasan proses pembelajaran dapat dilakukan melalui kegiatan pemantauan, supervisi, evaluasi, pelaporan serta tindak lanjut yang dilakukan secara berkala dan berkelanjutan. berdasarkan hasil yang diperoleh dari angket guru, siswa dan kepala sekolah diperoleh presentase sebesar $90 \%$ dengan kriteria sangat baik. Hal ini dapat diketahui bahwa proses pengawasan pembelajaran sudah dilaksanakan dengan sangat baik di SMP kecamatan Sumur. Berikut presentase pernyataan angket indikator pengawasan pada gambar 5 di bawah ini.

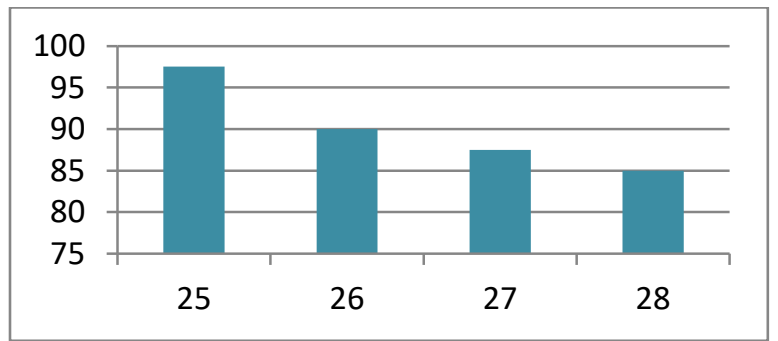

Gambar 5. Grafik presentase angket pada indikator pengawasan

Dalam hal pemantauan proses pembelajaran biasanya dilakukan melalui pengamatan oleh kepala sekolah ketika pembelajaran berlangsung, dimana dalam hal melakukan kunjungan kelas untuk memastikan guru melaksanakan RPP yang telah disusunnya memperoleh presentase sangat tinggi yaitu $97,5 \%$ pada pertanyaan nomor 25 . Hal ini dapat diartikan bahwa kepala sekolah sering melaksanakan proses pemantauan kepada guru yang mengajar. Proses pemantauan yang dilakukan oleh kepala sekolah dilakukan setiap minggu, namun ketika pembelajaran yang dilakukan secara daring selama pandemi covid19 dengan bergabung ke pembelajaran daring yang sedang dilaksanakan untuk mengawasi guru dalam melaksanakan proses pembelajaran.

Dalam hal mengadakan kegiatan supervisi dimana kepala sekolah sering mengadakan pertemuan dengan guru-guru diawal semester untuk merencanakan pelaksanaan pembelajaran pada semester yang bersangkutan dan pertemuan diakhir semester untuk mengevaluasi pelaksanaannya memperoleh presentase sangat tinggi sebesar 90\% pada pertanyaan nomor 26 . Dimana ketika sebelum pandemi covid-19 berlangsung kepala sekolah mengadakan kegiatan supervisi berupa pertemuan dengan dewan guru setiap 3 bulan sekali di awal dan di akhir semester untuk membahas perencanaan pembelajaran, dan kepala sekolah sering menyarankan kepada guru agar melakukan proses dan hasil belajar siswa memperoleh presentase sebesar 87,5 pada pertanyaan nomor 27 dengan kriteria sangat baik. Hal tersebut dapat diketahui bahwa kepala sekolah melaksanakan kegiatan supervisi akademik secara baik.

Selain itu dalam hal proses tindak lanjut dalam pengawasan pembelajaran kepala sekolah memberikan berupa penghargaan kepada guru yang memiliki kinerja sangat baik atau telah melampaui standa dengan presentase $85 \%$ pada pertanyaan nomor 28. Hal tersebut dilakukan oleh kepala sekolah untuk meningkatkan profesionalisme guru, sedangkan dalam mengatasi kinerja guru yang kurang yaitu dengan memberikan pembinaan pengembangan keterampilan mengajar guru dengan pemberian contoh misalnya berupa pelatihan, diskusi, dan konsultasi.

\section{KESIMPULAN}

Berdasarkan hasil dan pembahasan dapat disimpulkan bahwa proses pembelajaran IPA terpadu dalam pelaksanaan kurikulum 2013 di SMP kecamatan Sumur secara keseluruhan sudah dilaksanakan dengan baik, hal tersebut dapat dilihat dari perolehan hasil rata rata indikator perencanaan sebesar 80,6\%, pelaksanaan pembelajaran $71,8 \%$, penilaian 75,2 , sedanggkan 
indikator pengawasan sebesar 90\%. Namun ditemukan kendala dalam proses pembelajaran IPA terpadu dalam pelaksanaan kurikulum 2013 yaitu pemahaman mengenai keterpaduan yang sesuai dengan kurikulum 2013, serta masih banyaknya guru yang menggunakan metode ceramah ketika pembelajaran berlangsung. Hal ini menyebabkan siswa menjadi kurang aktif pada saat pembelajaran berlangsung serta pembelajaran menjadi kurang optimal

\section{DAFTAR PUSTAKA}

Benyamin S. Bloom. (1981). All Our Children Learning. Mc Graw-Hill Book Company: New York.

Cochran, K.F., DeRuiter, J.A, dan King, R.A. (1993) Pedagogical Content Knowing: An Integrative Model For Teacher Prearation . Journal Of Teacher Education, 44 (4): 263272.

Fogarty, R. (1991). How to Integrate the Curricula. Palatine Illinois: Skylight Publishing.

Radimah, Irawan. B \& Hindarsti, N.E.K. (2019). Analisis Proses Pembelajaran IPA SeKecamatan Siantan Timur Kabupaten Kepulauan Anambas. Artikel E-Journal Biologi. Program Studi Pendidikan Biologi Universitas Maritim Raja Ali Haji.

Shafa. (2014). Karakteristik Proses Pembelajaran Kurikulum 2013. Dinamika Ilmu Vol. 14. No 1., 81-96.
Setiawati Dewi, G.A. (2013). Pemanfaatan Subak Dalam Pembelajaran IPA (Upaya Mewujudkan Pembelajaran IPA Yang Mendukung Implementasi Kurikulum 2013). Seminar Nasional FMIPA Undiksha III Tahun 2013.

Septiana, N. et al. (2018) 'Kesulitan Mengajar Ipa Terpadu Guru IPA SMP/MTS Di Kalimantan Tengah', Edu Sains: Jurnal Pendidikan Sains \& Matematika, 6(1), p. 1. doi: 10.23971/eds.v6i1.716.

Yulianti. 2014. Tingkat keterlaksanaan implementasi kurikulum 2013 Dalam pembelajaran Biologi SMA Negeri di Kabupaten Dompu tahun ajaran 2013/2014. Artikel. Program Studi Pendidikan Biologi: FMIPA Universitas Mataram.

Prasetiyono, S. (2014). Pengembangan Media Pembelajaran E-Learning Berbasis Edmodo Pada Kompetensi Dasar Menerapkan Konsep Dasar Sistem Komunikasi Data Sinyal Digital Melalui Media Kabel Fiber Dan Frekuensi Radio Di SMK Negri 1 Jetis Mojokerto. Jurnal Pendidikan Teknik Elektro, Vol. 3, No. 2.

Peraturan Mentri Pendidikan Nasional_Nomor 22 Tahun 2016 Tentang Standar Proses Untuk Satuan Pendidikan Dasar dan Menengah. 